\title{
Local Government Strategies in Health Protocol Education for People with Mental Disabilities in Ponorogo Regency by Strengthening Social Non-Governmental Organizations
}

\author{
Muhammad Farid Ma'ruf ${ }^{1, *}$, Galih Wahyu Pradana $^{2}$, Deby Febrian Eprlianto ${ }^{3}$, Suci \\ Megawati $^{4}$ \\ 1,2,3,4 Universitas Negeri Surabaya \\ *Corresponding author. Email: muhammadfarid@unesa.ac.ic
}

\begin{abstract}
Disabled people with different disabilities are one of the categories that are sensitive to COVID-19 infection. In dealing with COVID-19 and for people with disabilities, prevention policies have been issued by the government. Because of its limits, the regulation must be properly implemented, since disabled individuals need helpers to do their activities. Education on health practices is therefore highly crucial for people with disabilities. The purpose of this study is to outline the strategy of local governments to educate health protocols for individuals with mental disabilities through the strengthening of Ponorogo's social NGOs. The results of the study reveal that local authorities, including persons with disabilities, have a significant role to play in lobbying for community health protocols. Health protocol education for people with disabilities can be conducted inter alia by (a) involving a sign language speaker; (b) develop guidelines for the implementation of inclusive communication and information provision, and (c) create a service guide for the online class. The education of the health protocol is direct or indirect. The participation of social nongovernmental organizations is one of the health protocol education tactics in Ponorogo Regency for disabled people. Rumah Harapan Karangpatihan Community is one of the NGOs directly active in the education of disabled persons on health protocols in their village. Education for families with disabilities remains informative. In order to limit direct interaction, Rumah Harapan activists often co-ordinate social support from outside parties. Unfortunately, the optimization of the protocol health education process for persons with disabilities is not coordinated well between Rumah Harapan and related authorities in Ponorogo Regency. It is nevertheless obvious that people with impairments in their daily activities have not followed the health protocol.
\end{abstract}

Keywords: Government Strategies, Health Education Protocols, People with Mental Disabilities, Nongovernmental Organization

\section{INTRODUCTION}

Reading disability is defined as the consequence of interactions between persons who have physical or mental/intellectual limitations and attitudes and surroundings that limit their capacity to participate fully and equally in society with other people. People with disabilities suffer economic, physical, social, and other consequences as a result of the COVID-19 epidemic. Persons with disabilities are groups of individuals who have physical or mental impairments that limit their involvement and engagement in social activities. Article 
20 of Law No. 8 of 2016 Concerning Persons with Disabilities regulates the connection of government duty to persons with disabilities in the context of disaster protection [1].

Persons with Disabilities have the right to: obtain easily accessible information about a disaster, gain knowledge about disaster risk reduction, receive priority in the rescue and evacuation process in a disaster situation, obtain facilities and means of rescue and evacuation that are easily accessible and receive priority. During the Covid-19 epidemic, the Indonesian government took different measures to ensure the rights of individuals with disabilities, according on statistics from the National Economic Census performed by the Central Statistics Agency in 2012, which totaled to 6,008,661 people. Through Government Regulation No. 13 of 2020 Concerning Adequate Accommodation for Students with Disabilities, the government ensures the continuity of education for people with disabilities [2].

Local governments are expected to develop policies that promote protection for people with disabilities in accordance with their particular authority. This policy plan will be investigated in Ponorogo Regency, East Java, which has 5,033 individuals with disabilities out of 124,622 people with disabilities in East Java, according to the 2018 Central Statistics Agency census data [3]. The number of persons with mental impairments is 98 ; this data is very noteworthy because the majority of mentally retarded people live in Karangpatihan hamlet, Balong sub-district, which is the primary site of this research. People with mental impairments have multiple restrictions ranging from restricted physical functions to limited activities, participation obstacles, and environmental constraints. Their awareness of the practice of health procedures during the Covid 19 epidemic has a significant influence.

Based on this circumstance, the surrounding community's participation in disaster protection for persons with mental impairments is required. The problem in this research study is focused on this function and concern in the context of education for individuals with mental impairments. In the form of a policy brief, this study aims to describe the role and concern of the surrounding community in educating health protocols for people with mental disabilities in Ponorogo Regency, as well as to recommend appropriate health protocol education strategies for people with mental disabilities in Ponorogo Regency. Attention should be paid to the understanding of people with mental impairments on the implementation of health procedures during the COVID-19 pandemic. The responsibility of the nearest community is required to carry out disaster protection duties and satisfy the rights of individuals with mental impairments. This study is anticipated to produce suggestions for collaboration and suitable educational techniques for people with disabilities in crisis circumstances, namely the COVID19 pandemic.

Strategic management is made up of two terms: management and strategy. Stephanie and K. Marrus claim [4] Strategy is described as the process of developing senior executives' plans that focus on the organization's long-term goals, as well as the development of a technique or endeavor to attain these goals. Nawawi then exposes the following formulations: strategic management, essentially managerial efforts to build and develop organizational strengths in order to capitalize on chances that emerge in order to achieve the goals that have been set in line with the mission that has been defined. Strategic management is a managerial effort to grow and develop organizational strengths that requires top management, with or without the assistance of subordinate managers, to identify aspects of the organization that are in accordance with the mission that must be developed in order to achieve the strategic objectives that have been established. Strategic management is a series of decisions and activities that result in the creation of a successful strategy or plan to aid in the achievement of corporate goals [4].

Strategic management is a large-scale planning (strategic planning) that is oriented to the far future reach (vision) and is determined as a top management decision (fundamental and primary decisions) in order to enable the organization to interact effectively (mission) in order to produce something (planning). operational operations to create quality goods or services and services aimed at optimizing the organization's aims (strategic goals) and target-based (operational goals). SWOT analysis is a popular approach in strategic management (Strengths, Weaknesses, Opportunities, and Threats) [5].

Social support is information or feedback from others that demonstrates that a person is loved and cared for, appreciated and respected, and part of a network of mutual communication and duties [6]. Meanwhile, according to Ganster, et al in Apollo \& Cahyadi [7] The availability of a connection that is helpful and has unique value for the one who gets it is referred to as social support. Cohen and Syme appear in Apollo and Cahyadi [7] are resources offered by others to individuals that can have an impact on the individual's well-being. Further social support by House \& Khan in Apollo \& Cahyadi [7] is a beneficial activity that includes emotions, knowledge, instrumental aid, and a favorable evaluation of persons in coping with their issues. Cohen and Hoberman in Isnawati and Suhariadi [8] highlighted that social support refers to the many resources made available by a person's interpersonal interactions. 
According to Sarafino in Purba [9] found that there are five different forms of social assistance, which are as follows:

1. Emotional support includes emotions of empathy, compassion, and worry for persons. Typically, this assistance is provided by a spouse or family member, such as by offering an understanding of the issues being encountered or by listening to their concerns. The availability of this support will give the individual with a sense of comfort, assurance, belonging, and love.

2. Positive expression or favorable appreciation for individuals, encouragement to continue forward, or validation of individual thoughts or sentiments, and positive comparisons of persons with others are all examples of appreciation support. Typically, this assistance is supplied by superiors or coworkers. This sort of assistance will foster sentiments of value, competence, and worth.

3. This form of help, known as instrumental or tangible support, comprises direct assistance. Typically, this support is provided by friends or coworkers, such as assistance with completing duties that have piled up or lending money or other items that the individual requires. The availability of commodities (things) or the availability of services from other people who can assist persons in solving their issues is described as the existence of this assistance. Furthermore, this will make it easier for employees to carry out their obligations in their everyday roles.

4. Individuals might receive information assistance in the form of guidance, ideas, or comments. This assistance is typically provided by friends, coworkers, superiors, or a professional such as a doctor or psychologist. The availability of information assistance, such as advice or recommendations from others who have been in a similar position, will assist individuals in understanding the issue and looking for alternate solutions to problems or actions to take.

5. Support for the individual concerned is provided by social network support, network support by creating a sense that the individual is a member of a specific group and has similar interests, a sense of connection with group members. The availability of social network support will assist individuals in reducing stress by satisfying the desire for friendship and social contact with others. It will also assist the individual in diverting his focus away from his difficulties or in enhancing his positive attitude.

Through the Decree of the Minister of Health of the Republic of Indonesia Number HK.01.07/MENKES/382/2020 concerning Health Protocols for the Community in Public Places and Facilities in the Context of Corona Virus Prevention and Control, the government issued five protocols or guidelines that apply to the community during the Covid 19 pandemic. [10]. Health protocols are rules and regulations that all parties must follow. The government has established protocols in the following areas: a) health protocols, b) communication protocols, c) border control protocols, d) education area protocols, and e) public area and transportation protocols. The protocol is being implemented across Indonesia under the supervision of the Ministry of Health, and includes:

1) If you feel sick with the criterion of temperature 38 degrees Celsius and cough/runny nose, relax at home and take vitamins as needed; if problems persist or develop with trouble breathing, get care at a health service institution promptly. Use a mask throughout treatment; if you don't have one, observe appropriate cough/sneeze etiquette by covering your mouth and nose with a tissue or the back of your hand, and avoid taking public transit. 2) Health professionals at health facilities will screen suspicious Covid 19: if you match the requirements, you will be directed to one of the hospitals; if you do not meet the criteria, you will be hospitalized or treated as an outpatient, based on the diagnosis and the doctor's choice. 3). If you match the Covid 19 requirements, you will be transported to a referral hospital by ambulance, escorted by a health professional who is wearing PPE. 4) Specimens will be obtained for laboratory evaluation and treated in an isolation facility at the referral hospital. 5). The samples will be submitted to the Jakarta-based Health Research and Development Agency.

The initial examination's findings will be available within 24 hours of the specimen's receipt. If the test is affirmative, you are classified as a Covid 19 patient. Every day, samples will be obtained, and you will be released from the isolation chamber if the sample examination findings are negative two days in a row. If the test results are negative, you will be treated based on the etiology of the condition. However, if you are in good health: 1) There is a history of travel 14 days ago to a nation afflicted by Covid 19, or 2) You believe you have been in contact with a person infected with Covid 19, then call the Corona Hotline Center at 199 ext 9 for additional advice.

The definition of disability is detailed in Law No. 8 of 2016 Concerning Persons with Disabilities [1]. Persons with Disabilities are defined as anybody who has longterm physical, intellectual, mental, and/or sensory impairments, according to the Act. The implementation 
and fulfillment of the rights of people with disabilities are based on the following principles: a) respect for dignity, b) individual autonomy, c) nondiscrimination, d) full participation, e) human and humanitarian diversity, f) equal opportunity, g) equality, h) accessibility, and I ever-evolving capacity and identity.

The realization of complete and equal respect, promotion, protection, and fulfillment of human rights and basic freedoms for Persons with Disabilities; guarantee efforts to respect, promote, protect, and fulfill rights as inherent dignity for Persons with Disabilities; realize a more qualified, fair, physically and mentally prosperous, independent, and dignified standard of living for Persons with Disabilities; protect Persons with Disabilities from neglect and exploitation, harassment and all discriminatory actions, as well as violations of human rights; and ensure the implementation of efforts to respect, promote, protect, and fulfill the rights of Person with disability.

\section{METHODS}

This study was carried out in Ponorogo Regency, which has three villages, namely Sidoharjo Village (Pulung), Krebet Village (Jambon), and Karangpatihan Village (Balong), whose people have various mental impairments. The qualitative method is used in this study [11]. Purposive sampling was used to identify informants in the study, who were thought to be competent about the COVID-19 pandemic health protocol education approach for persons with mental impairments in Ponorogo Regency. The data was gathered using the following methods: literature review, field survey/observation, focus group discussion (FGD), and in-depth interview. The obtained data is examined utilizing qualitative data analysis methodologies.

\section{RESULTS AND DISCUSSION}

Support for individuals with disabilities is part of the national development aim of achieving justice and welfare for everyone (kemensos.go.id). According to Katc and Kahn (2000), social support is defined as good sentiments, like, trust, and attention from other people, namely individuals who are significant in the individual's life, acknowledgment, one's trust, and direct help in some way. Social support also aids in the strengthening of immunological function, the reduction of physiological reactions to stress, and the strengthening of functions in response to chronic illness. Taylor et al [12] highlighted the significance of social assistance for persons with disabilities, particularly in terms of giving knowledge about the situation during the Covid-19 epidemic.

\subsection{Social Support for Persons with Disabilities}

Based on the research results Husmiati et al [13] Support for People with Mental Disabilities (Tunagrahita) is not limited to providing medicines; social support from the community is also essential. Observations were made at the study site for persons with mental impairment by as many as 97 members of the social non-governmental organization Rumah Harapan. The Hope House is a non-governmental organization that provides care and social assistance to mentally retarded individuals in Karang Kepatihan Village. This mentally retarded person in Karang Patihan Village became well-known to many people, beginning with news on one television program about the state of mentally retarded, which the TV program dubbed the idiot village, so that gradually the name idiot village went viral, and many people visited and provided assistance. One of those who heard the news was from the Bina Grahita Center for Social Rehabilitation, which came to visit and provided a program of counseling and teaching mentally handicapped individuals to become economically independent. However, before the program can be implemented, it must be overseen by an institution or community.

By taking into account the significant number of mentally retarded people in the village, the Head of Karang Kepatihan Village initiates the establishment of a social NGO in line with the guidance of the Center for Social Rehabilitation of Bina Grahita. The village head transferred the LKS Manager to one of the village's community leaders, Mr. Ji, who then took care of the Social Non-Governmental Organization's licensing through a lengthy procedure, and ultimately the permission was finalized and designated the Rumah Harapan Social Self-Help Institution. The Rumah Harapan Social Non-Governmental Organization initiative collects statistics on mentally retarded persons. The Rumah Harapan Social Non-Governmental Organization, assisted by the Social Service of Ponorogo Regency, has also implemented an electronic Identity Card Program for Homes for the Mentally Retarded, which is carried out with a ball pick-up system, door to door recording of persons with disabilities, and the production of electronic Identity Cards.

People with mental impairment who are helped by the Rumah Harapan Social Non-Governmental Organization have an electronic ID card that they utilize to get government social welfare aid, which helps to alleviate some of the economic load. People with mental impairment who were supported by the Rumah Harapan Social Non-Governmental Organization received coaching, training in the manufacturing of handcraft goods, and simple schooling. The Rumah Harapan Social Non-Governmental Organization gradually 
received sympathy and support from many parties, providing material and non-material assistance, and then a pavilion/secretariat was built, which became a center for meetings, training, and craft making by Rumah Harapan Social Non-Governmental Organization members.

The Rumah Harapan Social Non-Governmental Organization's operations may be characterized as an endeavor to offer attention, facilities given by community members in preventing and rehabilitating individuals with disabilities. This is consistent with the Mental Health First Aid Action Plan, which notes that community assistance might take the form of: (1) Approaching, detecting, and assisting in any crisis; (2) Listening without judgment; (3) Providing necessary support and information; (4) Encouraging suffering to seek appropriate professional treatment; and (5) Encouraging with various forms of support.

The Rumah Harapan Social Non-Governmental Organization's program is becoming more popular, with visits from members of the general public, Provincial and Regency Government officials, Ministers to President Jokowi, and members of the community. All of the products (mats, batiks, livestock documentation, etc.) created by mentally challenged persons are sold to tourists and the larger community at the Rumah Harapan Social Non-Governmental Organization's Pendopo/secretariat.

However, during the COVID-19 pandemic, the product-making operations at the Pendopo were temporarily halted because to the health vulnerabilities of the Rumah Harapan management, who implemented this policy so that the production of foot mats and batik was carried out in their separate houses. The mentally retarded present the final product to the Rumah Harapan management at the pavilion and are promptly paid for their effort and supplies. The administrator of Rumah Harapan provides free product supplies. During the Covid-19 pandemic, Rumah Harapan members congregated in the pavilion to socialize if there were guests.

Social support in the form of help for people with disabilities (particularly those who are mentally impaired) need specialized knowledge and skills. Ife, as cited by Udiati and Tursilarini [14] sets a criterion that the companion's competence has three dimensions, namely knowledge, abilities, and values relevant to the necessary sector of employment.

As shown by the effectiveness of Rumah Harapan in accommodating and empowering mentally retarded people, it can be inferred that there is excellent social support from the community for mentally retarded persons with disabilities in Karangpatihan Village. This can serve as a model for other local governments to follow in terms of providing social assistance for individuals with disabilities in accordance with national development goals, namely the creation of justice and welfare for everyone.

\subsection{Health Protocol Education for Persons with Disabilities}

On March 30, 2007, the Indonesian government signed the Convention on the Rights of Persons with Disabilities in New York. The signing demonstrates the State of Indonesia's commitment to respect, defend, fulfill, and promote the rights of people with disabilities. As a result of the treaty, the Government of Indonesia ratified it through the Law of the Republic of Indonesia No. 19 of 2011 Concerning Ratification of the Convention on the Rights of Persons with Disabilities (Convention on the Rights of Persons with Disabilities). According to the convention, "people with disabilities" are individuals who have long-term physical, mental, intellectual, or sensory impairments that interact with different barriers that may prevent them from participating fully and effectively in society on an equal footing with others.

In addition, the Rights of Persons with Disabilities are specified in Law No. 8 of 2016 Concerning Persons with Disabilities. Provisions regarding the rights of people with disabilities in education, for example, may be found in Article 5, which states: "People with disabilities have rights: a) live; b) free from stigma; c) privacy; d) justice and legal protection; e) education; f) employment, entrepreneurship, and cooperatives; g) health; h) politics; i) religious; j) sports; k) culture and tourism; 1) social welfare; m) accessibility; n) public services; o) protection from disasters; $\mathrm{p}$ ) habilitation and rehabilitation; q) concessions; r) data collection; s) live independently and be involved in society; t) express, communicate, and obtain information; $u$ ) change of place and nationality; and v) free from acts of discrimination, neglect, torture and exploitation."

According to Astuti, as stated by Murni and Astuti, the government and local governments have duties under the legal framework, one of which is to satisfy the needs of community groups with disabilities (disabled) [15]. Physical and information accessibility According to the findings of a research study done in the Ponorogo area of East Java, there were no particular programs or regulations for people with disabilities during the Covid19 outbreak.

Although the Ponorogo Regency Government has not yet developed a strategy for the management and education of Covid-19 for people with disabilities, there are government rules that apply to everyone, such as COVID-19 prevention and health protocols. General information for the general audience. The findings of Jayanegara's research may be linked back to this condition wich indicates that the development of 
learning designs for persons with impairments in Indonesia is still limited [16].

Rumah Harapan educates its fostered individuals about health protocols through appeals, such as wearing masks when performing activities at the pavilion during the Covid-19 epidemic. For example, when a visitor arrives, fostered members are gathered and taught to wear masks. They were extremely obedient and refused to remove their masks until the ceremony was done. Health education activities for people with disabilities are conducted in a variety of ways, either directly or indirectly.

Furthermore, Rumah Harapan makes the most of the function of the closest family members in conveying various health procedures directly to people with disabilities. In addition, distribution is carried out through intermediaries, media, and instruments that may be utilized as a means of communication and understanding the character of individuals with mental retardation who can assist success in communicating, as done by Rumah Harapan volunteers. In the home setting of persons with mental impairment, health procedures are also taught by relatives and neighbors. The good news is that no cases of the COVID-19 pandemic have been reported from mentally retarded persons in the community, despite the rising stereotype that people with impairments have superior immunity or endurance. However, because this has not been scientifically verified, it requires further investigation.

According to the results of interviews with Rumah Harapan management, there was no government assistance for health protocol tools such as masks and hand sanitizers and others; instead, more assistance came from outside parties who visited, such as student activities at the pavilion involving fostered members, who provided masks, hand sanitizer, and others. If there is a lack of health care goods (masks, hand sanitizer, and other items) for individuals with disabilities' everyday requirements.

It may be inferred that families, neighboring communities, and the administration of Rumah Harapan give education on health procedures for people with disabilities. In this place, the government's role in education has not yet been adopted

\section{CONCLUSION}

Based on the findings of the study, it is possible to infer that teaching about health procedures for individuals with mental retardation during the Covid-19 pandemic originates from families, neighboring communities, and the administration of Rumah Harapan. In this place, the government's role in education has not yet been adopted. It is suggested that municipal governments, in particular, give education to individuals with disabilities as a means of promoting justice for all.

\section{ACKNOWLEDGMENTS}

The research team would like to thank all parties who have helped this research to run smoothly. We would also like to express our gratitude to the Institute for Research and Community Service (LPPM), State University of Surabaya for providing funding support for this research.

\section{REFERENCES}

[1] Undang-Undang Republik Indonesia No. 8 tahun 2016 tentang Penyandang Disabilitas, No Title. 2016.

[2] Peraturan Pemerintah No. 13 Tahun 2020 tentang Akomodasi yang Layak untuk Peserta Didik Penyandang Disabilitas, No Title. .

[3] BPS Kabupaten Ponorogo, "Statistik Daerah Kabupaten Ponorogo," Kabupaten Ponorogo, 2018. [Online]. Available: https://ponorogokab.bps.go.id/publication.html?P ublikasi\%5BtahunJudul\%5D=2018\&Publikasi\% 5BkataKunci\%5D=\&Publikasi\%5BcekJudul\%5 $\mathrm{D}=0 \& \mathrm{yt} 0=$ Tampilkan.

[4] I. Nawawi, Manajemen Strategi Sektor Publik. CV. Dwiputra Pustaka Jaya, 2010.

[5] H. Umar, Strategi Management In Action (Konsep, Teori, dan Teknik Menganalisis Manajajemen Strategis). PT. Gramedia Pustaka Utama, 2008.

[6] L. A. King, Psikologi umum: Sebuah Pandangan Apresiatif, 3rd ed. Jakarta: Salemba Humanika, 2012.

[7] Apollo and A. Cahyadi, "Konflik Peran Ganda Perempuan Menikah Yang Bekerja Ditinjau Dari Dukungan Sosial Keluarga Dan Penyesuaian Diri," Widya War. No. 02 Tahun XXXV I, vol. 000, no. 02, pp. 230-239, 2012.

[8] F. Isnawati, Dian \& Suhariadi, "Hubungan Antara Dukungan Sosial Dengan Penyesuaian Diri Masa Persiapan Pensiun Pada Karyawan PT Pupuk Kaltim. Jurnal Psikologi Industri Dan Organisasi," J. Psikol. Ind. dan Organ., vol. 2, no. 1, pp. 2-7, 2013, [Online]. Available: http://journal.unair.ac.id/filerPDF/110810263_rin gkasan.pdf.

[9] J. Purba, A. Yulianto, and E. Widyanti, 
"Pengaruh dukungan sosial terhadap burnout pada guru [effetct of social support on school teacher's burnout]," J. Psikol., vol. 5, no. 1, pp. 77-87, 2007, [Online]. Available: https://digilib.esaunggul.ac.id/public/UEUJournal-4982-johanaP.aries.pdf.

[10] K. M. K. R. I. N. H. 01. 07/MENKES/382/202. tentang P. K. bagi M. di T. dan F. U. dalam R. P. dan P. C. Virus, No Title. .

[11] Sugiyono (2016), "Metode Penelitian," Metod. Penelit., 2016.

[12] S. E. Taylor, Health Psychology (Edisi ke-10), 10th ed. New York: McGrow-hill Companies, 2018.

[13] H. Yusuf, "Masalah Psikososial Keluarga dan Peranan Psikoedukasi dalam Peningkatan Kualitas Hidup Bekas Pesakit Mental Abstrak Family Psychosocial Problem and Role of Psychoeducation in the Improvement of the Quality of Life of the Ex Mental Patient Abstract Pengena," Asian Soc. Work J., vol. 2, no. 2, pp. 19-25, 2017.

[14] T. Udiati and T. Y. T. Tursilarini, "Eksistensi pendamping sosial dalam penangangan permasalahan kesejahteraan sosial," Media Inf. Penelit. Kesejaht. Sos., vol. 44, no. 3, pp. 239252, 2020, doi: https://doi.org/10.31105/mipks.v44i3.2346.

[15] M. Astuti and R. Murni, "Tinjauan Yuridis Dan Empiris Pemenuhan Hak-Hak Penyandang Disabilitas Berat," Sosio Inf., vol. 2, no. 3, pp. 215-228, 2016, doi: 10.33007/inf.v2i3.273.

[16] I. N. Jayanegara, I. N. A. F. Setiawan, and G. A. M. Putri, "Design of Interactive Multimedia Learning Vocabulary for Students Communication Disorder and Deafness During the Covid-19 Pandemic," IJDS Indones. J. Disabil. Stud., vol. 7, no. 2, pp. 239-248, 2020, doi: 10.21776/ub.ijds.2020.007.02.12. 